УДК $376: 004$

Нетьосов Сергій Іванович

кандидат педагогічних наук, доцент кафедри педагогіки та корекційного навчання Дніпропетровський національний університет імені Олеся Гончара, м. Дніпро,Україна netyosov.sergiy@gmail.com

\title{
ВИКОРИСТАННЯ ПРОГРАМНО-АПАРАТНОГО ЗАБЕЗПЕЧЕННЯ В ПРОЦЕСІ КОРЕКЦЇ̈ ВАД СЛУХУ ТА МОВЛЕННЯ У ДІТЕЙ
}

\begin{abstract}
Анотація. Проаналізовано результати самооцінювання студентами спеціальності «Корекційна освіта» рівня власної готовності до використання програмно-апаратного забезпечення в процесі корекції слухомовленнєвих вад у дітей. 3'ясовано, що рівень готовності студентів до використання програмно-апаратного забезпечення логопедичного та сурдопедагогічного характеру не відповідає вимогам сьогодення. Визначено види програмно-апаратного забезпечення, їхні функціональні можливості, використання яких разом $з$ традиційними методиками корекційної роботи позитивно впливають на розв'язання проблем діагностування i корекції слухомовленнєвих вад особистості. Запропоновано комплекс заходів із формування у студентів спеціальності «Корекційна освіта» готовності до застосування програмно-апаратного забезпечення логопедичного i сурдологічного спрямування в процесі корекційно-педагогічної діяльності.
\end{abstract}

Ключові слова: логопедія; сурдопедагогіка; програмно-апаратне забезпечення; діагностика; корекція; сурдомовленнєві вади.

\section{1. ВСТУП}

Постановка проблеми. Розвиток інформаційного суспільства відкриває людству нові ефективні шляхи, методи та підходи у розв'язанні актуальних проблем в усіх сферах життя. Сучасні цифрові технології системно використовуються в освітній діяльності, що позитивно відбивається на результативності навчання, виховання та розвитку особистості [10-12].

Для підвищення якості традиційних методів корекційно-педагогічної роботи 3 дітьми, які мають вади сурдологопедичного характеру, нині у галузі спеціальної педагогіки широко використовується підклас інформаційно-комунікаційних технологій у вигляді програмно-апаратного забезпечення (ПАЗ) - сукупність програм обробки інформації, апаратів, устаткування і технічних засобів, що дозволяють автоматизувати процеси виконання комплексу завдань корекційного спрямування, забезпечують функціонування електронних інформаційних ресурсів i систем корекційнорозвивального напряму.

Продуктивність корекційно-освітнього процесу 3 використанням ПАЗ, оптимізація роботи дефектолога на занятті шляхом створення ігрового середовища, різноманітність форм подання навчального матеріалу, що сприяє активізації мимовільної уваги, підвищенню мотивації до навчання, можливість постійного контролю за діяльністю і іï результатами, регулювання оптимального темпу i складності виконання кожною дитиною завдання зумовлюють актуальність проблеми використання ПАЗ у системі діагностування і корекції вад слухомовленнєвого характеру.

Аналіз останніх досліджень та публікацій. У системі спеціальної освіти дослідження фахівців спрямовувалися на узагальнення питань психологопедагогічного, методичного та дидактичного використання ПАЗ у корекційнорозвивальному процесі. Застосування сучасного забезпечення у роботі з дітьми різних 
нозологій у своїх працях аналізували: Д. П. Димитриченко, Л. А. Дітковська, В. В. Кабак, К. О. Косова, М. Ю. Кадемія, О. О. Майданчик, О. М. Пилюгін, І. Б. Порецький, . С. Ракачов, М. А. Рощина, Ю. Й. Тулашвілі, Г. Є. Цейтлін, О. В. Чеботарьова, В. В. Черних, Л. З. Шауцукова, В. І. Швецов та інші.

Значна увага приділяється питанню використання ПАЗ майбутніми фахівцями спеціальної освіти такими дослідниками, як О. Б. Качуровська, О. Є. Кітік, 3. О. Мотилькова, Т. В. Папернова, В. В. Соколовська, І. В. Федоренко, М. К. Шеремет та іншими. Науковці, розглядаючи питання ефективності застосування навчальних комп'ютерних програм у процес професійної підготовки логопедів, зосереджують увагу на тому, що компетентність у використанні ПАЗ педагогом системи спеціальної освіти є складовою загальної інформаційної культури спеціаліста, досліджують стан готовності вчителів-дефектологів до роботи 3 комп'ютерними технологіями, визначають теоретичні підходи до організації комп'ютерно-інформаційної підготовки студентів-дефектологів, рівні сформованості інформаційної компетентності студентівлогопедів, розробляють напрями використання сучасних комп'ютерних технологій учителем-логопедом, обгрунтовують дидактичні і методичні вимоги до застосування ПАЗ на занятті вчителями системи спеціальної освіти.

Мета статті полягає в тому, щоби на підставі аналізу самооцінювання студентами спеціальності «Корекційна освіта» рівня власної готовності до використання ПАЗ в процесі корекції слухомовленнєвих вад у дітей, а також визначення видів і функцій ПАЗ, які доцільно впроваджувати в систему роботи логопеда і сурдопедагога, запропонувати комплекс заходів з формування готовності студентів до застосування ПАЗ логопедичного і сурдологічного спрямування у корекційно-педагогічній роботі.

\section{2. РЕЗУЛЬТАТИ ДОСЛІДЖЕННЯ}

Для виявлення рівня готовності студентів спеціальності «Корекційна освіта» ДНУ ім. О. Гончара у використанні ПАЗ діагностичного і сурдологопедичного спрямування кафедрою педагогіки та корекційної освіти було проведено анкетування студентів I-IV курсів. В опитуваннях узяли участь 140 осіб (I курс - 43 студенти, II курс - 36 студентів, III курс - 39 студентів, IV курс - 22 студенти).

Респондентам було поставлено завдання: «Визначте власний рівень готовності до використання ПАЗ, якими у своїй діяльності може скористатися вчитель-логопед та сурдопедагог». Пропонувалося обрати такі варіанти відповідей: вільно використовують у роботі ПАЗ із функціями корекції слухомовленнєвих вад (високий рівень); уміють працювати з ПАЗ із функціями корекції слухомовленнєвих вад, але мають певні труднощі (достатній рівень); для використання ПАЗ із функціями корекції слухомовленнєвих вад потребують системної консультації фахівця (середній рівень); мають загальне уявлення про ПАЗ із функціями корекції слухомовленнєвих вад (початковий рівень); відмовляються від оцінювання рівня власної готовності до використання ПАЗ з функціями корекції слухомовленнєвих вад.

Отримані дані за результатами анкетування подані в табл. 1.

Під час оцінювання студентами рівня власної готовності до використання ПАЗ із функціями корекції слухомовленнєвих вад з'ясувалося, що 54 студенти $(38,6$ \%) взагалі не оцінили свій рівень, 53 особи (37,9\%) визначили свій рівень початковим, 21 респондент $(15 \%)$ - середнім і тільки 12 студентів-респондентів $(8,5 \%)$ визначили свій рівень готовності достатнім (9 осіб - 6,4 \%) та високим (3 студенти $-2,1 \%)$. 
Таблиияя 1

Самооцінка студентами-респондентами спеціальності «Корекційна освіта» ДНУ ім. О. Гончара рівня власної готовності до використання ПАЗ для корекції слухомовленнсвих вад

\begin{tabular}{|c|c|c|c|c|c|}
\hline \multirow{2}{*}{$\begin{array}{c}\text { Критерії суб'єктивного } \\
\text { оцінювання студентами- } \\
\text { респондентами рівня } \\
\text { власної готовності до } \\
\text { використання ПАЗ для } \\
\text { корекції слухомовленнєвих } \\
\text { вад }\end{array}$} & \multirow[t]{2}{*}{ Курс } & \multicolumn{2}{|c|}{$\begin{array}{c}\text { Кількість студентів-респон- } \\
\text { дентів, які суб’ єктивно } \\
\text { визначили свій рівень } \\
\text { готовності до використання } \\
\text { ПАЗ для корекції } \\
\text { слухомовленнєвих вад }\end{array}$} & \multicolumn{2}{|c|}{$\begin{array}{c}\text { Усього студентів- } \\
\text { респондентів за } \\
\text { рівнями готовнос- } \\
\text { ті до використан- } \\
\text { ня ПАЗ для корек- } \\
\text { ції слухомовлен- } \\
\text { нєвих вад }\end{array}$} \\
\hline & & $\begin{array}{c}\text { К-ть } \\
\text { студентів- } \\
\text { респонден- } \\
\text { тів курсу }\end{array}$ & $\begin{array}{c}\text { \% від } \\
\text { кількості } \\
\text { студентів- } \\
\text { респонденів } \\
\text { курсу } \\
\end{array}$ & $\begin{array}{l}\text { Заг. } \\
\text { к-ть } \\
\text { студ.- } \\
\text { респ. }\end{array}$ & $\begin{array}{c}\% \\
\text { від заг. } \\
\text { кільк. } \\
\text { студ.- } \\
\text { респ. }\end{array}$ \\
\hline \multirow{4}{*}{$\begin{array}{l}\text { Мають загальне уявлення } \\
\text { про ПАЗ із функціями } \\
\text { корекції слухомовленнєвих } \\
\text { вад (початковий рівень) }\end{array}$} & $\mathrm{I}$ & 13 & 30,2 & \multirow{4}{*}{53} & \multirow{4}{*}{37,9} \\
\hline & II & 10 & 27,8 & & \\
\hline & III & 21 & 53,9 & & \\
\hline & IV & 9 & 40,9 & & \\
\hline \multirow{4}{*}{$\begin{array}{lr}\text { Для використання ПАЗ із } \\
\text { функціями корекції слухо- } \\
\text { мовленнєвих вад потребу- } \\
\text { ють } & \text { системної } \\
\text { консультації } & \text { фахівця } \\
\text { (середній рівень) } & \end{array}$} & $\mathrm{I}$ & 7 & 16,3 & \multirow{4}{*}{21} & \multirow{4}{*}{15} \\
\hline & II & 5 & 13,9 & & \\
\hline & III & 5 & 12,8 & & \\
\hline & IV & 4 & 18,2 & & \\
\hline \multirow{4}{*}{$\begin{array}{l}\text { Уміють працювати } 3 \text { ПАЗ } \\
\text { iз функціями корекції } \\
\text { слухомовленнєвих вад, але } \\
\text { стикаються } 3 \text { певними } \\
\text { труднощами } \\
\text { (достатній рівень) }\end{array}$} & $\mathrm{I}$ & 2 & 4,7 & \multirow{4}{*}{9} & \multirow{4}{*}{6,4} \\
\hline & II & 0 & 0 & & \\
\hline & III & 7 & 17,9 & & \\
\hline & IV & 0 & 0 & & \\
\hline \multirow{4}{*}{$\begin{array}{l}\text { Вільно використовують у } \\
\text { роботі ПАЗ } 3 \text { функціями } \\
\text { корекції слухомовленнєвих } \\
\text { вад (високий рівень) }\end{array}$} & $\mathrm{I}$ & 1 & 2,3 & \multirow{4}{*}{3} & \multirow{4}{*}{2,1} \\
\hline & II & 0 & 0 & & \\
\hline & III & 1 & 2,6 & & \\
\hline & IV & 1 & 4,5 & & \\
\hline \multirow{4}{*}{$\begin{array}{l}\text { Відмовились від оціню- } \\
\text { вання рівня власної готов- } \\
\text { ності до використання } \\
\text { ПАЗ з функціями корекції } \\
\text { слухомовленнєвих вад }\end{array}$} & $\mathrm{I}$ & 20 & 46,5 & \multirow{4}{*}{54} & \multirow{4}{*}{38,6} \\
\hline & II & 21 & 58,3 & & \\
\hline & III & 5 & 12,8 & & \\
\hline & IV & 8 & 36,4 & & \\
\hline \multicolumn{4}{|l|}{ Усього } & 140 & 100 \\
\hline
\end{tabular}

У підсумку можемо констатувати, що 128 студентів (91,5\%) спеціальності «Корекційна освіта» не мають або мають достатньо обмежене уявлення про характер і функціональні можливості ПАЗ, спрямованого на корекцію вад слухомовленнєвого характеру (рис. 1). 


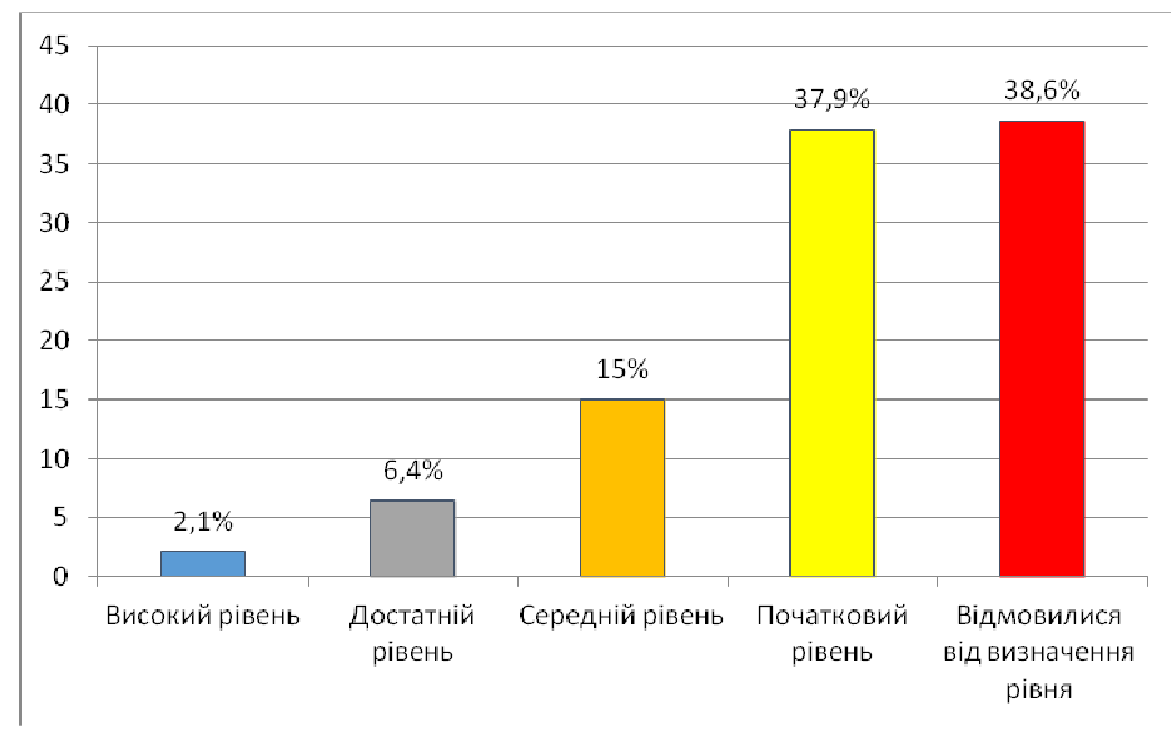

Рис. 1. Діаграма самооцінки студентами-респондентами спеціальності «Корекиійна освіта» ДНУ ім. О. Гончара рівня власної готовності до використання ПАЗ для корекиї слухомовленнєвих вад

На основі отриманих результатів вважаємо за потрібне презентувати й надати загальну характеристику ПАЗ, у першу черг,у для студентів спеціальності «Корекційна освіта», а також інших зацікавлених осіб, запропонувати заходи 3 організації розв'язання проблеми формування готовності студентів зазначеної спеціальності до використання ПАЗ у корекційно-педагогічній роботі.

Назва, види та призначення ПАЗ, застосування яких забезпечує корекцію вад сурдологопедичного характеру подані у табл. 2.

Таблиияя 2

\section{Перелік ПАЗ для проведення корекції вад сурдологопедичного характеру}

\begin{tabular}{|c|c|c|}
\hline Назва & Види & Призначення \\
\hline «Лонгітюд» & $\begin{array}{l}\text { Експертний } \\
\text { програмний комплекс }\end{array}$ & $\begin{array}{l}\text { Діагностування проблемних зон розвитку } \\
\text { дитини і розробка індивідуальних } \\
\text { рекомендацій з подолання виявлених вад }\end{array}$ \\
\hline $\begin{array}{c}\text { «Цицерон. } \\
\text { ЛОГО діакорр } \\
1 » \\
\end{array}$ & $\begin{array}{l}\text { Інноваційна } \\
\text { здоров'язберігаюча } \\
\text { програмна технологія }\end{array}$ & $\begin{array}{l}\text { Проведення діагностики ф індивідуальної } \\
\text { корекції немовленнєвих психічних } \\
\text { функцій }\end{array}$ \\
\hline «Глобус» & $\begin{array}{l}\text { Універсальний } \\
\text { діагностико- } \\
\text { слухомовленнєвий } \\
\text { прилад-тренажер }\end{array}$ & $\begin{array}{l}\text { Діагностика слухомовленнєвих вад і } \\
\text { проведення занять з розвитку мовлення у } \\
\text { слабочуючих і глухих дітей }\end{array}$ \\
\hline «Логомір» & $\begin{array}{l}\text { Програмно- } \\
\text { дидактичний } \\
\text { комплекс } \\
\text { інтерактивних ігор і } \\
\text { поліграфічних } \\
\text { матеріалів }\end{array}$ & $\begin{array}{l}\text { Діагностика й проведення індивідуальних } \\
\text { і групових занять із корекції } \\
\text { слухомовленнєвих вад }\end{array}$ \\
\hline $\begin{array}{c}\text { «Звуковий } \\
\text { калейдоскоп» }\end{array}$ & $\begin{array}{l}\text { Збірник } \\
\text { інтерактивних ігор }\end{array}$ & $\begin{array}{l}\text { Діагностика рівня мовленнєвого слуху, } \\
\text { розвиток фонематичного слуху і } \\
\text { звукобуквеного аналізу }\end{array}$ \\
\hline
\end{tabular}




\begin{tabular}{|c|c|c|}
\hline «Дельфа - 130» & $\begin{array}{l}\text { Комп'ютерний } \\
\text { тренажер }\end{array}$ & $\begin{array}{l}\text { Організація і проведення тренувально- } \\
\text { корекційних вправ логопедичного } \\
\text { характеру }\end{array}$ \\
\hline «Дельфа - 142» & $\begin{array}{l}\text { Комп'ютерний } \\
\text { тренажер }\end{array}$ & $\begin{array}{l}\text { Формування усного та писемного } \\
\text { мовлення у дітей з психофізичними } \\
\text { вадами }\end{array}$ \\
\hline «Монолог» & $\begin{array}{l}\text { Електронний } \\
\text { тренажер }\end{array}$ & $\begin{array}{l}\text { Комплексна реабілітація людей з будь- } \\
\text { якими формами заїкання і закріплення } \\
\text { навичок корекції мови }\end{array}$ \\
\hline $\begin{array}{l}\text { «Гри для } \\
\text { Тигри» }\end{array}$ & $\begin{array}{l}\text { Спеціалізована } \\
\text { комп’ ютерна } \\
\text { технологія }\end{array}$ & $\begin{array}{l}\text { Корекція загального недорозвинення } \\
\text { мовлення }\end{array}$ \\
\hline $\begin{array}{l}\text { «Починаю } \\
\text { говорити» }\end{array}$ & $\begin{array}{l}\text { Набір інтерактивних } \\
\text { ігор і вправ }\end{array}$ & $\begin{array}{l}\text { Проведення навчальних занять із дітьми } \\
\text { дошкільного віку }\end{array}$ \\
\hline «Видима мова» & $\begin{array}{l}\text { Програмно-апаратний } \\
\text { комплекс }\end{array}$ & Формування і корекція усного мовлення \\
\hline «Живий звук» & $\begin{array}{l}\text { Програмно-апаратний } \\
\text { методичний } \\
\text { комп'ютерний } \\
\text { комплекс }\end{array}$ & $\begin{array}{l}\text { Організація і проведення корекційно- } \\
\text { компенсаторного навчання дітей із } \\
\text { функціональними обмеженнями } \\
\text { слухомовленнєвого характеру }\end{array}$ \\
\hline
\end{tabular}

Для розширення спектра інформованості студентів спеціальності «Корекційна освіта», логопедів та сурдопедагогів щодо діагностики, профілактики, корекції слухомовленнєвих вад на основі сучасних експертних систем, тренажерів, програм існує необхідність виявлення можливостей, аналізу змісту, характеристик, особливостей, функцій та напрямів використання ПАЗ, поданих у табл. 2.

Розглянемо групу ПАЗ, використання яких разом із забезпеченням корекційних сурдологопедичних функцій дозволяє здійснювати діагностику слухомовленнєвих проблем особистості.

Програмний комплекс «Лонгітюд» - експертна система, за допомогою якої здійснюється первинне обстеження і діагностика проблемних зон розвитку дитини. Основний діагностичний метод, застосований у комплексі, - Шкала розвитку, що стандартизована на нормативній популяції з необтяженим анамнезом і спрямована на первинне визначення рівня і виявлення відхилень у розвитку без аналізу їх причин i можливої специфіки, обумовленої складним анамнезом. Шкала розвитку може бути використана для обстеження дітей з обтяженим анамнезом, але не призначена для детального клінічного дослідження розвитку таких дітей, іiї завдання - привернути увагу до проблеми [9].

За результатами обстеження на основі Шкали розвитку рекомендаційний блок експертної системи пропонує індивідуальну «Програму розвитку». Теоретикометодологічною основою підготовки індивідуальних рекомендацій $\epsilon$ ідеї Л. С. Виготського про зону найближчого розвитку дитини як ключового діагностичного принципу виховання і навчання.

Експертна система пропонує низку корекційних комплексів для занять 3 дитиною на найближчі 3-6 місяців. Заняття спрямовані на розвиток соціально-адаптивних функцій, сприйняття, пізнавальної активності, діяльності, культурно-гігієнічних навичок та самообслуговування, фізичного і мовленнєвого розвитку. Для корекції розвитку слухомовленнєвих вад дітей програма «Лонгітюд» пропонує рекомендації й ігри, спрямовані на слухове зосередження, розуміння мови (пасивний словник), активне мовлення (у т. ч. граматичної будови). 
Отже, для проведення скрінінгової діагностики проблемних зон розвитку дитини, корекції виявлених слухомовленнєвих вад експертна система «Лонгітюд» буде корисна дефектологу, логопеду, сурдопедагогу, психологу, олігофренопедагогу, неврологу $[6 ; 8 ; 9 ; 13]$.

Центром діагностики i психолого-педагогічного супроводу родини й дитини «Цицерон» розроблена здоров'язберігаюча технологія об'єктивізованої діагностики, профілактики, цілеспрямованої корекції немовленнєвих і мовленнєвих функцій дітей «Цицерон.ЛОГО діакорр 1», що призначена також для формування індивідуальної програми психолого-педагогічного супроводу дитини і забезпечення успішної соціалізації [16].

Функцію діагностування, разом 3 іншими проблемами сурдологопедичного характеру, реалізує також універсальний прилад-тренажер «Глобус». Апарат забезпечує обстеження стану слухової функції особистості, індивідуальний вибір посилення i частотного діапазону на кожне вухо окремо, залежно від рівня збереженості слуху людини; як тренажер апарат використовується для проведення слухомовленнєвих занять сурдопедагогами у спеціалізованих дошкільних i шкільних закладах. Особливістю й перевагою апарату є можливість передавати звукові сигнали через вібротактильні відчуття, що відображають акустичну структуру слів, що вимовляються. Робота з вібратором попереджує безголосе, тихе або гучне мовлення [3].

Діагностичні функції у корекційно-педагогічній діяльності 3 дітьми, які мають слухомовленнєві вади, реалізуються в процесі роботи з блоками інтерактивних ігор, які включені до програмно-дидактичного комплексу «Логомір» і набору ігор «Звуковий калейдоскоп».

Комплекс «Логомір» містить 60 інтерактивних ігор, які можуть бути використані логопедом або дефектологом для оцінювання словникового запасу дитини і іï вмінь граматично правильно будувати своє мовлення. Включення комплексу ігор до традиційної системи корекційної роботи логопеда i сурдопедагога створює можливість для вдосконалення системи дихальних вправ дитини, розвитку фонематичного і немовленнєвого слуху, аналізу складової структури слів, корекцію вимовляння звуків, читання, загальної і дрібної моторики, розвитку логіки, уваги та зв'язного мовлення [14].

Набір інтерактивних ігор «Звуковий калейдоскоп» надає фахівцям можливість досліджувати рівень мовленнєвого слуху, розвивати фонематичний слух, проводити звуковий і буквений аналіз слова тощо.

Отже, використання ПАЗ для проведення корекції вад сурдологопедичного характеру надає можливість логопеду й сурдопедагогу провести скрінінгову діагностику слухомовленнєвих вад дитини, сприяє визначенню характеру слухового порушення, дає можливість оцінити стан слухової функції, з'ясувати обсяг словникового запасу і рівень психомоторного розвитку особи. На основі використання запропонованих ПАЗ створюється можливість розробки індивідуального плану корекційного впливу, контролю за ефективністю психофізичної корекційної діяльності.

Для успішної організації корекційної роботи логопеду та сурдопедагогу поряд із традиційними методами доцільно використовувати комп'ютерні тренажери «Дельфа$130 » \mathrm{i}$ «Дельфа-142».

За допомогою комп'ютерної технології «Дельфа-130» створюється ігрове середовище, на базі якого вирішуються корекційні завдання сурдологопедичного спрямування, забезпечується постійний контроль за діями дитини, регулюється оптимальний темп виконання кожною дитиною завдань різної складності. Підвищення ефективності корекційного процесу досягається шляхом забезпечення зорового контролю за формуванням навичок вимовляння [15].

Електронний тренажер «Дельфа-142» забезпечує корекцію мовлення дитини. Можливість корекційної діяльності на основі використання тренажеру 3 різними 
рівнями складності забезпечує організацію корекційної роботи з дітьми, у яких, попри слухові та мовленнєві вади, є порушення опорно-рухового апарату, інтелекту. Попри це, система дозволяє враховувати особливості зорового сприйняття і пам'яті дітей 3 мовленнєвою патологією [5].

До групи електронних тренажерів належить також апарат «Монолог», що призначений для реабілітації осіб, які страждають будь-якими формами заїкання. Функціональні можливості апарату забезпечують приглушення або посилення звуку, ритмічну стимуляцію і відтворення мови 3 певною затримкою. Зазначені функції реалізуються в умовах індивідуального режиму роботи з кожною людиною і сприяють поліпшенню мовлення, розширенню комунікативних і адаптаційних можливостей особистості.

Опору на зорове сприйняття в процесі слухомовленнєвої корекції реалізує спеціалізована комп'ютерна логопедична програма «Ггри для Тигри». Активізація компенсаторних механізмів, формування стійких візуально-кінестетичних умовнорефлекторних зв'язків центральної нервової системи, формування правильних мовленнєвих навичок реалізується на основі серії вправ: «Вимовляння звуків», «Просодіка», «Фонематика» та «Лексика». Програмно-методичний комплекс адресований логопедам і дефектологам, але більше ніж 50 комп'ютерних вправ із детальними методичними рекомендаціями можуть використовуватися і батьками для самостійних занять 3 дітьми в домашніх умовах [3; 7].

Для розвитку фонематичного слуху, пам'яті та логічного мислення у роботі 3 дітьми дошкільного віку доцільно використовувати набір інтерактивних ігор «Починаю говорити». Обираючи рівень складності гри, педагог-дефектолог, логопед або батьки на основі цікавих інтерактивних комп'ютерних матеріалів можуть вирішувати питання співвіднесення голосного звуку та букви, опанування словника дієслів, повторення звуків, поповнення лексичного запасу, розвитку уваги.

Важливе місце у корекційно-педагогічній діяльності сурдологів та логопедів належить програмно-апаратному комплексу Speech viewer («Видима мова»). Він застосовується для забезпечення формування та корекції усного мовлення дитини, починаючи з дворічного віку. При використанні цього ПАЗ на моніторі відображаються акустичні компоненти мови. Методичне супроводження допомагає фахівцям зрозуміти, які завдання у сфері формування та корекції мовлення доцільно вирішувати за допомогою комплексу, як ефективно включати роботу з комп'ютером у традиційні індивідуальні заняття 3 дитиною, як програма допомагає контролювати та демонструвати особі «просування» в розвитку мовленнєвих навичок [4; 13].

Серед ПАЗ, призначених для організації педагогічно-корекційної діяльності вчителя-логопеда, спеціалісти та розробники в Україні виокремлюють апаратнопрограмний методичний комплекс «Живий звук», розроблений НВП «ВАБОС». Комплекс призначений для організації та проведення корекційно-компенсаторного навчання дітей із функціональними обмеженнями, у першу чергу слухомовленнєвого характеру.

У корекційно-розвивальній програмі «Живий звук» застосовано педагогічний підхід диференціації фонем за доступністю сприймання, розпізнання їх зором, слухом i тактильно, послідовності їх формування у дитини 3 порушенням слуху, враховуючи близькість/віддаленість фонем за частотними характеристиками, пріоритетності сенсорних систем у сприйманні і розпізнаванні. Програма забезпечує реалізацію полісенсорного впливу на розвиток дитини, організацію ігрової стратегії корекційнопедагогічного впливу, доступності й послідовності навчання, складається з трьох функціональних частин: бази даних, графічної візуалізації мовлення, модулів корекційно-розвивального навантаження [1;2]. 
На основі використання корекційно-розвивальної програми «Живий звук» фахівець системи корекційної освіти має можливість підвищити ефективність діяльності в напрямі розвитку мовлення дитини, яка має сенсорні й інтелектуальні порушення. Особливе місце в технічному i методичному забезпеченні програми займають проблеми розвитку наочно-дійового, наочно-образного та словесно-логічного мислення, ігрової і пізнавальної діяльності дитини. Зазначені підходи дозволяють вчителю-дефектологу, психологу, логопеду, сурдопедагогу використовувати корекційно-розвивальну програму «Живий звук» для організації корекційнокомпенсаторного навчання дітей з функціональними обмеженнями і в домашніх умовах для роботи батьків із дитиною.

Отже, використання ПАЗ відкриває додаткові можливості для логопедів, сурдологів, дефектологів, психологів та інших фахівців спеціальної освіти в діагностуванні і корекції проблем слухомовленнєвого характеру. Застосування сучасних програм, тренажерів, апаратів та комп'ютерних ігор у корекційному процесі забезпечує реалізацію нових підходів до організації і проведення логопедичної i сурдопедагогічної роботи 3 кожною дитиною індивідуально, створює додаткові можливості врахування специфічних проблем кожної особи. Включення ПАЗ у традиційну систему корекційної освіти надає додаткові можливості для людей зі специфічними потребами у слухомовленнєвій сфері для отримання сучасної освіти, оволодіння конкурентоспроможною спеціальністю, входження в активне суспільне життя.

\section{3. ВИСНОВКИ ТА ПЕРСПЕКТИВИ ПОДАЛЬШИХ ДОСЛІДЖЕНЬ}

Проаналізувавши результати самооцінювання студентами спеціальності «Корекційна освіта» рівня власної готовності до використання ПАЗ з метою корекції слухомовленнєвих вад особи, було з'ясовано, що рівень їх готовності не відповідає вимогам сьогодення. За результатами вивчення характеристик існуючих програмнодидактичних комплексів, тренажерів, наборів інтерактивних ігор вважаємо за потрібне підкреслити, що нині існує багатий арсенал ПАЗ, які в поєднанні з традиційними методиками спеціальної системи освіти відкривають додаткові можливості розв'язання проблем діагностування і корекції слухомовленнєвих вад дітей.

Використання ПАЗ у процесі діагностування слухомовленнєвих вад дає можливість виявити проблемні зони розвитку дитини, визначити характер слухового порушення, оцінити ступінь ураження і стан слухової функції, з'ясувати обсяг словникового запасу, охарактеризувати психомоторний розвиток особи, що відкриває шлях до складання індивідуального плану корекційного впливу на дитину та забезпечує контроль над ефективністю реалізації запропонованих заходів.

Визначено, що використання ПАЗ сурдологопедичного спрямування у поєднанні 3 традиційними методиками корекції слухомовленнєвих вад сприяє формуванню у дитини правильних мовленнєвих навичок, забезпечує реабілітацію осіб із будь-якими формами заїкання, відкриває шлях до вирішення питань постійного контролю за діями в процесі сурдологопедичної корекції, надає можливість активізувати компенсаторні механізми людини.

Вважаємо, що для підвищення рівня готовності студентів спеціальності «Корекційна освіта» до використання ПАЗ діагностично-корекційного характеру логопедичного і сурдопедагогічного спрямування, практичного опанування майбутніми фахівцями методики застосування сучасних засобів у системі традиційної корекційнорозвивальної роботи, необхідно реалізувати такі заходи: 
- розробити спецкурс, спрямований на опанування студентами методики використання ПАЗ у логопедичній i сурдопедагогічній корекційно-розвивальній діяльності;

- включити певні розділи і теми 3 аналізу сучасних ПАЗ логопедичносурдологічного характеру в програми спеціальних дисциплін;

- створити систему постійно діючих семінарів із питань удосконалення методики роботи 3 логопедичними та сурдопедагогічними програмами, комплексами, тренажерами корекційно-розвивального спрямування;

- забезпечити практичну підготовку студентів спеціальності «Корекційна освіта» в установах системи спеціальної освіти, де активно використовують ПАЗ у навчальновиховному і корекційно-розвивальних процесах. Включити до переліку обов'язкової документації за результатами практики студентів звіти з аналізом відкритих заходів, що проводяться логопедами i сурдопедагогами високої кваліфікації, які досконало володіють методикою застосування ПАЗ у традиційній системі корекційнорозвивальної роботи з дітьми зі слухомовленнєвими вадами.

У подальшому вважаємо за потрібне, по-перше, проаналізувати готовність студентів спеціальності «Корекційна освіта» ДНУ ім. О. Гончара до використання ПАЗ у роботі з дітьми, які мають вади зору та інтелектуального розвитку, по-друге, дослідити ефективність заходів 3 підвищення рівня готовності студентів зазначеної спеціальності до використання ПАЗ у корекційній діяльності з дітьми різних нозологій.

\section{СПИСОК ВИКОРИСТАНИХ ДЖЕРЕЛ}

1. ВАБОС - слуховые аппараты [Электронный ресурс]. - Режим доступа: http://vabos.com.ua

2. Використання універсального комп'ютерного тренажеру з корекційно-розвиваючою програмою «Живий звук» в процесі а/реабілітації дітей 3 порушеннями слуху та мовлення в Центрі слухомовленнєвої реабілітації НВП «ВАБОС» [Електронний ресурс] / Т. В. Богданович, Д. М. Заїка, В. О. Конюшняк та ін. - Режим доступу: http://csr-vabos.com.ua/Vikoristanya

3. Витаскан. Логопедическое оборудование и ПО [Электронный ресурс]. - Режим доступа: http://vitascan.ru/product

4. Гарнюк Л. Г. Застосування програмно-технічного комплексу «Видима мова» в корекційній роботі з глухими дітьми : автореф. дис. на здобуття наук. ступеня канд. пед. наук : спец. 13.00.03 «Корекційна педагогіка» / Л. Г. Гарнюк. - К., 2005. - 20 с.

5. Грибова О. Е. Методика работы с тренажёром «Дэльфа-142» [Электронный ресурс] / O. Е. Грибова. - Режим доступа: http://delfam.ru/gribova.html

6. Компанієць М. Н. Використання експертної системи «Логнітюд» в системі індивідуальної корекційної допомоги дітям з особливостями психофізичного розвитку / М. Н. Компанієць // Актуальні проблеми навчання та виховання людей в інтегрованому освітньому середовищі : тези доп. - К. : Університет «Україна», 2011. - 470 с. - Режим доступу : http://www.vmurol.com.ua/upload/Naukovo_doslidna\%20robota/Elektronni_vidannya/Zbirnik_tez2011.p df

7. Крохмаль В. М. Сучасні методики підвищення ефективності корекційного впливу при різних мовленнєвих порушеннях дітей дошкільного віку [Електронний ресурс] / В. М. Крохмаль. - Режим доступу : http://loippo-konsultacii.blogspot.com/2010/03/blog-post_05.html

8. Лонгитюд. Програмное обеспечение для психолога [Электронный ресурс]. - Режим доступа : http://testpsy.net/ru/

9. Методические материалы к программному комплексу для психологических исследований / под ред. С. А. Мирошникова - СПб. : Изд-во «ЛЕМА», 2014. - 194 с.

10.Нетьосов С. І. Використання ІКТ для управління загальноосвітніми навчальними закладами в умовах формування громадянського суспільства [Електронне видання] / С. І. Нетьосов // Інформаційні технології і засоби навчання. - 2013. - № 1 (33). - Режим доступу : http://journal.iitta.gov.ua

11. Нетьосов С. І. Використання інформаційно-комунікаційних технологій у системі виховної роботи вчителя історії / С. І. Нетьосов, С. Ф. Нетьосова // Психолого-педагогічні проблеми сільської школи : [зб. наук. праць]. - Умань : ПП Жовтий О.О., 2013. - Вип. 44. - С. 103 - 107. - Режим доступу : http://library.udpu.org.ua/library_files/psuh_pedagog_probl_silsk_shkolu/44/visnuk_16.pdf 
12. Нетьосов С. І. Інформаційно-комунікаційні технології у системі позакласної роботи вчителя історії / С. І. Нетьосов, С. Ф. Нетьосова // Наукові праці вищого навчального закладу «Донецький національний технічний університет». Серія : «Педагогіка, психологія і соціологія». - Вип. 1 (13), 2013. - Донецьк, 2013. - С. 279 - 285.

13. Нетьосов С. І. Формування інформаційної компетентності корекційного педагога / С. І. Нетьосов // Удосконалення підготовки корекційного педагога в умовах університетської освіти : моногр. / В. А. Гладуш та ін. - Д. : Акцент ПП, 2015. - С. 166 - 213.

14. Программно-дидактический комплекс «Логомер» [Электронный ресурс]. - Режим доступа : https://mersibo.ru/logomer

15. Сухорукова Г. Ф. Применение компьютерного тренажёра «Дэльфа-130» в коррекционной работе логопеда [Электронный ресурс] / Г. Ф. Сухорукова. - Режим доступа : http://festival.1 september.ru/articles/530720/

16. Центр диагностики и психолого-педагогического сопровождения семьи и ребёнка «Цицерон» [Электронный ресурс]. - Режим доступа : http://www.ciceroncenter.ru/product1-ru.shtml.

Матеріал надійшов до редакиї 17.05.2016 p.

\title{
ИСПОЛЬЗОВАНИЕ ПРОГРАММНО-АППАРАТНОГО ОБЕСПЕЧЕНИЯ В ПРОЦЕССЕ КОРРЕКЦИИ ПРОБЛЕМ СЛУХА И РЕЧИ У ДЕТЕЙ
}

\section{Нетёсов Сергей Иванович}

кандидат педагогических наук, доцент кафедры педагогики и коррекционного образования Днепропетровский национальный университет имени Олеся Гончара, г. Днепр, Украина netyosov.sergiy@gmail.com

\begin{abstract}
Аннотация. Проанализированы результаты самооценки студентами специальности «Коррекционное образование» уровня собственной готовности к использованию программно-аппаратного обеспечения в процессе коррекции проблем слуха и речи у детей. Выяснено, что уровень готовности студентов к использованию программно-аппаратного обеспечения логопедического и сурдопедагогического характера не соответствует требованиям сегодняшнего дня. Определены виды программно-аппаратного обеспечения, их функциональные возможности, использование которых вместе с традиционными методиками коррекционной работы позитивно повлияют на решение проблем диагностирования и коррекции слуховых и речевых проблем личности. Предлагается комплекс мероприятий по формированию у студентов специальности «Коррекционное образование» готовности к включению программно-аппаратного обеспечения логопедического и сурдологического характера в коррекционно-педагогическую деятельность.
\end{abstract}

Ключевые слова: логопедия; сурдопедагогика; программно-аппаратное обеспечение; диагностика; коррекция; слухоречевые проблемы.

\section{THE USE OF THE HARDWARE AND SOFTWARE IN THE PROCESS OF CORRECTION OF CHILDREN'S SPEECH AND HEARING DISORDERS}

\section{Sergiy I. Netosov}

Ph.D (Pedagogical Sciences), Associate Professor, Department of Pedagogy and Special Education Dnipropetrovsk National University Oles Honchar, Dnipro, Ukraine netyosov.sergiy@gmail.com

\begin{abstract}
The article introduces the self-evaluation of the ability to work with the hardware and software in the process of correction of children's speech and hearing disorders, given by the students of the "Correctional Education" Department. The research has shown that the students' readiness to use the hardware and software of logopaedic and surdopedagogic nature does not correspond to the present day requirements. The types of the hardware and software were defined, as well as their functional capabilities, the usage of which together with the traditional methods of correctional work positively affects the solution of the problems of the diagnostics and the correction of speech and hearing disorders. A set of measures is suggested to form the ability of
\end{abstract}


students from the "Correctional Education" Department to engage the hardware and software of logopaedic and surdologic nature in the process of correctional and pedagogical activity.

Keywords: logopaedics; surdopedagogy; the hardware and software; diagnostics; correction; speech and hearing disorders.

\section{REFERENCES (TRANSLATED AND TRANSLITERATED)}

1. VABOS - hearing aids [online]. - Available from: http://vabos.com.ua (in Russian).

2. The use of universal computer trainer with the correctional-and-educational program "Zhyvyi zvuk" in the process of rehabilitation of children with speech and hearing disorders in the Centre of speech and hearing rehabilitation Research-and-Production Enterprise "VABOS" [online] / T. V. Boghdanovych, D. M. Zajika, V. O. Konjushnjak and other. - Available from : http://csr-vabos.com.ua/Vikoristanya (in Ukrainian).

3. Vitascan. Logopedic hardware and software [online]. - Available from: http://vitascan.ru/product (in Ukrainian).

4. Garnyuk L. G. The use of software and hardware complex "visible speech" in correction working with deaf children: Author. dis. on competition sciences. degree candidate. ped. sciences specials. 13.00.03 "Correction pedagogy" / L. G. Garnyuk. - K., 2005. - 20 p. (in Russian).

5. Gribova O. E. The method works with the simulator "Delfa-142" [online] / O. E. Gribova. - Available from: http://delfam.ru/gribova.html (in Russian).

6. Kompaniyecz M. N. Use of expert system «Longityud» system of individual corrective care for children with special needs [online] / M. N. Kompaniyecz // Recent problems of training and educating people in an integrated educational environment - K. : University «Ukrayina», 2011. - 470 p. - Available from: :http://www.vmurol.com.ua/upload/Naukovo_doslidna\%20robota/Elektronni_vidannya/Zbirnik_tez2011. pdf (in Ukrainian).

7. Kroxmal V. M. Modern methods of improving the efficiency of corrective action at different speech disorders preschoolers [online] / V. M. Kroxmal. - Available from: http://loippokonsultacii.blogspot.com/2010/03/blog-post_05.html (in Ukrainian).

8. Longityud. Software for the psychologist [online]. - Available from: http://testpsy.net/ru/ (in Russian).

9. Methodical materials to software systems for psychological research / S. A. Myroshnykova - SPb.: «LEMA», 2014. - 194 p. - P. 31 - 32 (in Russian).

10. Netosov S. I. Use ICT to manage secondary schools in the formation of civil society [online] / S. I. Netosov // Information Technologies and Learning Tools. - 2013., № 1 (33). - Available from: http://journal.iitta.gov.ua (in Ukrainian).

11. Netosov S. I. The use of ICT in educational system Teacher of History [online] / S. I. Netosov, S. F. Netosova // Psycho-pedagogical problems of rural schools. - Uman, 2013. - Issue 44. - P. 103 - 107. Available http://library.udpu.org.ua/library_files/psuh_pedagog_probl_silsk_shkolu/44/visnuk_16.pdf from: Ukrainian).

12. Netosov S. I. Information and communication technologies in the system of extra-curricular activities of teachers History // S. I. Netosov, S. F. Netosova // Proceedings of higher education "Donetsk National Technical University ". Series: "Pedagogy, psychology and sociology"/ Issue 1 (13), 2013. - Doneck, 2013. - P. 279 - 285 (in Ukrainian).

13. Netosov S. I. Formation of information competence remedial teacher / S. I. Netosov // Improving the training of correctional educator in terms of university education : monograph / V. A. Hladush etc. Dnipropetrovsk, 2015. - P. 166 - 213 ( in Ukrainian).

14. Software and didactic complex «Logomer» [online]. - Available from: https://mersibo.ru/logomer (in Russian).

15. Suhorukova G. F. The use of a computer simulator «Djelfa-130" in the correctional work speech therapist / G. F. Suhorukova [online]. - Available from: http://festival.1september.ru/articles/530720/ (in Russian).

16. Center for diagnosis and psycho-pedagogical support of a family and a child «Ciceron» [online]. Available from: http://www.ciceroncenter.ru/product1-ru.shtml (in Russian).

Conflict of interest. The author has declared no conflict of interest.

\section{(cc) BY-NC-SA}

This work is licensed under Creative Commons Attribution-NonCommercial-ShareAlike 4.0 International License. 